\title{
YUMUŞAK GÜÇ VE FARKINDALIK ÜZERİNE BİR ÇALIŞMA
}

\section{Diler GÖKBAYRAKA ĞAÇDAN ${ }^{1}$}

Atıf/C: Gökbayrakağaçdan, Diler (2018). Yumuşak Güç ve Farkındalık Üzerinde Bir Çalışma, Hitit Üniversitesi Sosyal Bilimler Enstitüsü Dergisi, Yıl 11, Sayı 1, Haziran, ss. 781-788

Özet: Yumuşak Güç terimi son günlerde çok fazla duymakta olduğumuz bir terim haline gelmiştir. Amerikalı Profesör Joseph S. Nye tarafindan ortaya atılan bu terim, farkında olmasak da hayatımızın birçok bölümünde karşımıza çıkmaktadır. Dizi film izlerken, artık hayatımızın bir parçası haline gelmiş olan sosyal paylaşım sitelerinde sohbet ederken ve birçok benzeri faaliyette yumuşak güç kavramının etkileri altındayız. Tarihsel açıdan baktığımızda bu kavram ilk kez II. Dünya Savaşı'nda ortaya çıkmıştır. Dönemin Dişişleri Bakanı George Marshall tarafindan oluşturulan yardım fonu ile bu güçten Türkiye'de nasibini almıştır. Günümüzde ise Büyük Ortadoğu Projesi (BOP) adı altında yürütülen Ortadoğu ve Kuzey Afrika ülkelerine yönelik “demokratikleştirme” çalışmalar, yalnızca psikolojik bir savaşın ötesinde, batıl güçlerin çıkarları doğrultusunda bir amacı gerçekleştirmek için yapılan bir stratejidir. Çalışmada, yumuşak güç kavramının önemi ve farkındalığın nasıl geliştirilebileceği konusunda önerilere değinerek, daha fazla kitleye ulaşmak amaçlanmaktadır.

Anahtar Kelimeler: Yumuşak Güç, Nye, Marshall Planı, TİKA

Makale Gelis Tarihi: 11.10.2017// Makale Kabul Tarihi: 29.06.2018

Bu makale Turnitin programinda kontrol edildi. This article was checked by Turnitin.

${ }^{1}$ Ahi Evran Üniversitesi Uluslararası İlişkiler Anabilim Dalı Yüksek Lisans Mezunu,

dilergokbayrak@hitit.edu.tr

ORCID: 0000-0001-5247-1590 


\section{A Study on Soft Power and Awareness}

Citation/C:: Gökbayrakağaçdan, Diler (2018). A Study on Soft Power and Awareness, Hitit University Journal of Social Sciences Institute, Year 11, Issue 1, June, pp. 781-788

Abstract: Soft Power The term has become a term that we hear so much in recent days. American Professor Joseph S. The term coined by Nye, emerges in many parts of our lives if we are not aware of. Series of watching a movie, which has now become a part of our lives, and many other such activities while chatting on social networking sites are under the effects of the fact that the concept of soft power. When we look at the historical point of view, this concept for the first time. Emerged during World War II. Fund created by former Foreign Minister George Marshall received a grant this power in Turkey. Today, the Greater Middle East Projectcarried out under the name of the countries of the Middle East and North Africa for the "democratization" studies, only a psychological war, beyond the interests of the western powers in order to achieve a goal is a strategy made. In this study it is aimed to reach larger masses by mentioning the suggestions about the importance of soft power notion and how the awareness can be improved.

Keywords: Soft Power, Nye, Marshall Plant, TIKKA

\section{GÜÇ KAVRAMI VE YUMUŞAK GÜÇ}

Uluslararası politikanın en eski ve en temel kavramlarından birisidir güç. Tarih boyunca ortaya çıkan bütün devletler, belirli bir engelle karşılaşmadıkları sürece güçlerini artırmaya çalışmışlardır. Güç aktarımının önündeki en büyük engel ise, genellikle bir başka devletin varlığı ve gücü olmuştur. Bu nedenle üç ya da daha fazla devletin yer aldığı her uluslararası sistemde bir güç dengesi ilişkisine rastlamak mümkündür.(Sönmezoğlu, 2010:300)

Tayyar ARI gücün amacını çağdaş güç yaklaşımının ilk temsilcisi olan Hans J. Morgenthau'nun görüşü ile açıklamıştır: “Morgenthau'ya göre güç politikasının temel amacını ve herhangi bir siyasal davranışın temel güdüsünü oluştururken bir başka yerde güç kavramını bir ilişki biçimi veya amacı gerçekleştirmek için bir araç olduğunu ifade edebilmektedir.”(Arı, 2006:34) 
Morgenthau'ya göre, gücün kaynaklarının içerdiği unsurlar coğrafya, doğal kaynaklar, endüstri, askeri hazırlık, nüfus, ulusal karakter, ulusal moral, diplomasi ve hükümetin etkinliği olarak sıralanmaktadır.(Eralp, 2010:56)

Güç dediğimizde ilk akla gelen etkenler askeri ve ekonomik güçtür. Fakat yumuşak güç kavramı ilk defa ABD’li Profesör Joseph S. Nye tarafından ortaya atılmıştır. Joseph S. Nye yumuşak gücü, "Bir ülke dünya siyasetinde istediği sonuçları elde edebilir; çünkü onun değerlerine hayran olan, örnek alan, refah seviyesinde ve firsatlarına özenen diğer ülkeler onu izlemek ister. $\mathrm{Bu}$ anlamda sadece askeri güç tehdidini ya da ekonomik yaptırımları kullanarak diğerlerini değiştirmeye zorlamak değil, dünya siyasetinde gündemi oluşturmak ve onları kendine çekmekte önemlidir. Bu yumuşak güç, yani diğerlerinin senin istediğin sonuçları istemelerini sağlamak, insanları zorlamak yerine kendi yanına çeker."(Nye, 2005:14-15) şeklinde açıklamıştır.

Yumuşak güç her şeyden önce üç kaynağa dayanır, kültür, siyasi değerler ve diş politika.(Nye, 2005:20)

Kültürü bir toplumda en anlamlı ve değerli uygulamalar bütünü olarak tanımlandığı için öncelikle kültüre değinmek daha doğru olur kanaatindeyiz. Bir ülkenin kültürü, evrensel değerler içinde ve politikaları başkalarının da paylaştığı değerlere ve çıkarlara hizmet ettiğinde, yarattığı sorumluluk ve çekicilik ilişkileri sebebiyle, istediği sonuçları elde etme olasılığını artırır. (Nye, 2005:20)

Yurt içi ve yurt dişı hükümet politikaları da diğer bir potansiyel yumuşak güç kaynağıdır. Örneğin, 1950'lerde ülkedeki ırk ayrımı Amerika'nın Afrika'daki yumuşak gücünü azaltmıştır, bugün de ölüm cezasının uygulanması ve silah kontrolü yasalarının yetersizliği Amerika'nın Avrupa'daki yumuşak gücünü azaltmıştır. (Nye, 2005:20)

\section{KÜRESEL BİLGİ ÇAĞINDA YUMUŞAK GÜÇ}

Joseph S. Nye, Amerikan Gücünün Paradoksu adlı kitabında yumuşak gücü “Günümüz küresel bilgi çağında editörlerle yorumcuların öneminin artması yumuşak gücün görece öneminin artmasını da beraberinde getirmiştir. Çünkü yumuşak güç güvenilirliğe dayanır. Yumuşak gücü iyi oturmuş ülkeler daha iyi durumdadır." şeklinde yorumlayıp, bir bilgi çağında yumuşak güç kazanması muhtemel ilkeleri şu şekilde sınıflandırmıştır, "Baskın kültürü ve fikirleri egemen küresel normlara daha yakın olanlar, 
çoklu iletişim kanallarına en fazla erişim imkânına dolayısıyla konuların işlenmesine ve aktarılması konusunda daha fazla nüfuza sahip olanlar, güvenilirlikleri içteki ve uluslararası alanda performansıyla artanlar”. Bilgi çağındaki bütün bu boyutları, güç kaynaklarında oluşan karışım içinde gücün öneminin arttı̆̆ına işaret eder ki bu ABD'nin yararınadır.(Nye,2003:83)

Yaşadığımız bilgi çağındaki gelişmelere ve bunların uzantılarına bakarsak Profesör Nye’a katılmamak elde değildir. İletişim teknolojilerinin gelişmesi insanlarımız arasında sanal bir dünya kurup asosyal ve apolitik bireyler yetişmesinde büyük rol oynamaktadır. İnternet sitelerinde çokça rastladığımız sosyal paylaşım sitelerini, oyunları ya da sohbet programlarını kullanarak sanal şehirlerde, sanal arkadaşlıklarla hayatımızı devam ettirmekteyiz. Bu durum etrafımızda yaşanan olaylara, oynanan oyunlara tepkisiz kalmamızı sağlayarak üzerimizde uygulanan yumuşak gücün sadece bir örneğidir. Nye'ın da dediği gibi “ABD’nin uyguladığı yumuşak güç sadece hükümetin resmi icraatlarının bir ürünü olmaktan ziyade kısmen toplumun ve ekonominin bir yan ürünüdür.” (Nye,2003:88)

Dünya üzerinde uygulanan yumuşak güç örneklerine bakacak olursak, insanlık tarihinde bunun birçok uygulamasını görmekteyiz. Bunların ilki sayılabilecek olan ABD tarafindan II. Dünya Savaşı'ndan sonra uygulanan Marshall Planıdır. "Marshall Planı ve Türkiye üzerindeki etkileri" bazında Marshall Planından bahsetmek uygun olacaktır.

Marshall Planı II. Dünya Savaşı'ndan sonra ABD'nin Batı Avrupa ülkelerine yaptığı ve ABD'nin o dönemdeki Dışişleri Bakanı George MARSHALL'in adı ile anilan yardimdir.

Doğu Avrupa ülkelerinde Sovyetler Birliği’nin desteği ile Komünist Partiler iktidarı ele geçirirken, Batı Avrupa'da komünistlerin giderek güçlenmesi ABD’yi kaygılandırmıştır. Bu değerlendirme çerçevesinde ABD Dışişleri Bakanı Marshall Haziran 1947'de yaptığı konuşmada, gereksinimler belirlendiği takdirde ABD'nin Avrupa devletlerine yardım yapabileceğini açıklamıştır. Sonuçta 1948 yılı başlarında, saptanan gereksinimlere göre dört yıllık süre için "Ekonomik İşbirliği Kanunu" ABD tarafından kabul edilerek uygulamaya konulmuştur.(Sönmezoğlu, 2010:472) 
Marshall Planı Türkiye için ekonomik bağımlılığın başladığı yerdir. Bu ekonomik bağımlılık elbette birçok bağımlılığın başlangıcı rolünü üstlenmiştir.

ABD’nin uyguladığı güç elbette ki Marshall Planı ile sınırlı kalmamaktadır. Bunun diğer bir örneği Büyük Ortadoğu Projesi(BOP) olarak adlandırılan bölge ülke halklarının demokratik taleplerine ve kültürel ideolojilerine vurulmaya çalışılan bir darbedir. Bu projeyi Amerika'nın Ortadoğu ve kimi Kuzey Afrika bölgelerinde kültürel ve ekonomik bir yaptırım uygulama aracı olarak görmek mümkündür. Öyle ki bu proje zengin petrol yataklarının bulunduğu ülkelerde üstünlük elde etmeye çalışan batılı güçlerin emperyalist oyunu olarak algılanmasının yanı sıra Türkiye'nin de bu projeye dâhil edilerek "Model Ülke" rolü üstlenmesi ayrıca tartışılacak bir konudur.

Türkiye'nin uyguladığı ya da uyguladığının düşünüldüğü yumuşak güç araçlarına değinirsek, buna verebileceğimiz en önemli örnek herhalde TİKA projeleri olacaktır.

Türk İşbirliği ve Koordinasyon Ajansı Başkanlığı (TİKA) 24 Ocak 1992'de Bakanlar Kurulu Kararı ile kurulmuş ve 12 Mayıs 2001'de yürürlüğe girmiştir. Dış politikamıza aktif politika anlayışının yerleşmesi ile TİKA ortak değerlere sahip olduğumuz ülkeler başta olmak üzere birçok bölge ve ülkede Türk dış politikasını uygulayıcı bir aracı haline gelmiştir. Türk Cumhuriyetlerinin kendi sosyal yapısını üretmesi, kendi kimliğini sağlıklı bir şekilde inşa etmesi, kültürel ve siyasi hakların gelişmesi, teknik alt yap1 konusunda eksiklerin giderilmesi olarak özetleyebiliriz. Eğitim, sağlık, restorasyon, tarımsal kalkınma, maliye, turizm, sanayi alanında bir çok proje ve faaliyet TİKA tarafından gerçekleştirilmiş. TİKA Program Koordinasyon Ofislerinin ilki Türkmenistan'da açılmıştır ve ilerleyen dönemlerde Avrasya bölgesinde bulunan ofis sayısı 6'ya çıkmıştır. TİKA, ofislerinin bulunduğu ülkelerle beraber 5 kıtada 170'e yakın ülkede kalkınma merkezli işbirliği çalışmaları yapılmaktadır. Ülkemiz TİKA aracılığ ile Pasifik'ten Orta Asya'ya, Ortadoğu ve Afrika'dan Balkanlara, Kafkasya'dan Latin Amerika'ya kadar birçok ülkede çalışmalarına devam etmektedir. (Tika)

2011 yılında Yumuşak gücün farkındalığı açısından genelinde akademisyenler ve üniversite öğrencilerine tarafımdan uygulanan bir anket çalışmasına göre, katılımcıların sadece \%24,10'u Türkiye'nin yumuşak güç 
uyguladığ1 kanaatindedir. Bu oranın sadece \%9,3'ü TİKA projelerinin yumuşak güç uygulaması olduğunu düşünmektedir.

Katılımcıların \%51,90’1 "Yumuşak Güç" terimini daha önce hiç duymamış. Aynı oran ülkemiz üzerinde yumuşak güç uygulandığının bilincinde değildir. Bilincinde olan \%48,10'luk kısım ise yumuşak güç araçlarının çoğunluğunun yabancı diziler olduğunu belirtmektedir. Bu soruya Erasmus ve Unesco diyenlerin oranı ise hayli düşüktür. Peki bu uygulanan yumuşak gücü neden kabul ediyoruz sorusu geliyor akla. Bunun \%50'lik bir çoğunluğu özenti olduğunu yine azımsanmayacak çoğunlukta bir görüş ise caziplikten kaynaklandığını belirtiyor.

Diğer ülkelerin uyguladığı yumuşak güç ise katılımcıların \%40'ını tam anlamiyla olumsuz etkiliyor.

Yumuşak gücü en iyi uygulayan devlet sorulduğunda hiç şüphesiz ABD büyük bir oranla diğerlerinin önüne geçiyor. ABD’yi Avrupa Birliği ülkeleri, Çin, Japonya ve Türkiye takip ediyor. Türkiye'nin yumuşak güç uyguladığını katılımcıların \%24,10'u kabul ederken bu araçların en başında tarihi ve kültürel yakınlık olduğu dikkat çekmektedir. Türk dizileri, yabancı okullar ve TİKA'yı yumuşak güç aracı olarak göstermekteler. (Gökbayrak,2011)

Elbette ki katılımcıların düşünceleri çok önemlidir. Ancak şöyle bir gerçek de vardır ki ülkemiz vatandaşlarının yumuşak gücün farkındalığı konusunda biraz daha bilinçlendirilmesi gerekmektedir. Bazı yaklaşımlarda, uygulanan yumuşak gücün kimi kesimler tarafından inkâr etmeyerek kabullenildiği, hatta cazibesine kapıldığı bir memnuniyet göstergesidir

\section{SONUÇ}

Yapılan uygulama çalışmaları da dikkate alınırsa yumuşak güç ve etkilerinin özellikle az gelişmiş ve gelişmekte olan ülkeler üzerinde daha çok etkisi olduğu görülmektedir. Ulusların eğitim seviyesi ve demografik yapısı da yumuşak gücün uygulanmasında büyük önem taşımaktadır. Orta Doğu ülkelerine bakıldığında (www.aljazeera.com) tarihi ve kültürel yakınlıktan ziyade özellikle dizilerin ve filmlerin etkisinin fazla olması eğitim seviyesinin ilgi alanlarına nasıl yansıdığının göstergesidir. Genç nüfus üzerinde yaratılan farkındalığın çağımız teknolojilerinin kullanımı ile doğrudan ilişkisi olduğu söylenebilir. 
Yumuşak gücün, temelinde davranış açısından hayranlık uyandırma esasına dayanıyor olması, günümüzde bilinçlenmenin ve farkındalığın artırılmasındaki zorunluluğu gözler önüne sermektedir. Çünkü yumuşak güç, ekonomik ve askeri gücün aksine daha sinsi ve daha hissettirmeden uygulanmaktadir.

Özellikle bu farkındalığın oluşturulmasında akademik eğitim alanında müfredatlarda yumuşak güç kavramının daha fazla yer alması, kavram ile ilgili kitapların öğrencilere önerilmesi ve değerlendirme hususunda saha çalışmaları yapılarak akademik alanda çalışma imkânı bulamayan kişilere ulaşılması gerekmektedir.

Yumuşak gücün önemi ve toplumları nasıl etki alanına aldığı, uyandırılan hayranlık ve cazibenin toplum üzerindeki etkilerinin yer aldığı çalışmalara daha fazla yer verilmesinin farkındalığın artması açısından faydalı olacağı düşünülmektedir.

\section{KAYNAKÇA}

ARI, Tayyar, (2006), Uluslararası İlişkiler ve Dış Politika, İstanbul: Alfa.

ERALP, Atilla, (2010), Devlet ve Ötesi, İstanbul: İletişim.

NYE, Joseph, (2003), Amerikan Gücünün Paradoksu, (G.Koca,Çev.), İstanbul: Literatür.

NYE, Joseph, (2005), Dünya Siyasetinde Başarının Yolu Yumuşak Güç, (R.İnan Aydın,Çev.), Ankara: Elips.

SÖNMEZOĞLU, Faruk, (2010), Uluslararası İlişkiler Sözlüğü, İstanbul: Der

BAŞBAKANLIK TÜRK İŞBIRLIĞİ VE KOORDINASYON AJANSI BAŞKANLIĞI, "TIKKA Hakkında", http://www.tika.gov.tr/tr/sayfa/hakkimizda-14649 (31 Mayıs 2018)

GÖKBAYRAK, Diler, (2011), Yumuşak Güç, Ahi Evran Üniversitesi Sosyal Bilimler Enstitüsü Uluslararası İlişkiler Bölümü Ödevi.

http://www.aljazeera.com.tr/al-jazeera-ozel/turk-dizilerinin-rekoru (Son Erişim: 31 Mayis 2018) 